\title{
STRATEGI PEMERINTAH DAERAH DALAM MENINGKATKAN PENERIMAAN PAJAK KENDARAAN BERMOTOR JENIS SEPEDA MOTOR DI KALIMANTAN TENGAH
}

\author{
Kerlita
}

\begin{abstract}
ABSTRAK
Penelitian ini bertujuan untuk menjelaskan, mendeskripsikan dan menganalisis strategi pemerintah daerah serta faktor pendukung dan penghambat dalam meningkatkan penerimaan pajak kendaraan bermotor jenis sepeda motor di Kalimantan Tengah. Metode penelitian menggunakan penelitian deskriptif kualitatif. Hasil penelitian menunjukkan bahwa (1) Terdapat strategi Dipenda melalui koordinasi dan kerjasama, mobil SAMSAT keliling dan sosialisasi, sistem online dan pembebasan/sanksi administrasi pemungutan pajak/denda dan bunga. (2) Terdapat faktor pendukung, yaitu rajia dan sosialisasi dilakukan 4 kali dalam 1 tahun, 14 mobil SAMSAT Keliling. Sedangkan faktor penghambatnya, yaitu kurangnya koordinasi dan dukungan, kurang memperkenalkan mobil SAMSAT dan sosialisasi, kurangnya kualitas pelayanan dan kurang kesadaran wajib pajak.
\end{abstract}

\section{Keywords : Strategi pemerintah, pajak, sepeda motor}

\section{PENDAHULUAN}

Otonomi daerah merupakan salah satu bagian terpenting dalam meningkatkan berbagai sektor pembangunan yang ada di suatu daerah. Dengan adanya otonomi daerah, setiap daerah di dorong agar dapat mencari sumber penerimaan daerahnya guna mengisi keuangan daerah yang digunakan untuk membiayai anggaran belanja penyelenggaraan pemerintahan dan pembangunan yang ada di daerahnya masing-masing. Sumber penerimaan daerah yang digunakan untuk membiayai anggaran belanja daerah diperoleh melalui Pendapatan Asli Daerah (PAD). Pendapatan asli daerah merupakan pendapatan yang harus dikelola dan diatur dengan sebaik-baiknya.

Pendapatan asli daerah yang perlu diperhatikan penerimaannya di Kalimantan Tengah adalah pendapatan yang diperoleh dari pajak daerah, yakni pada pajak provinsi jenis Pajak Kendaraan Bermotor (PKB). Penerimaan pajak kendaraan bermotor ini perlu untuk diperhatikan, yakni supaya tidak terjadi kebocoran potensi pendapatan yang berpengaruh pada tingkat penerimaan PAD dan berdampak pada pembiayaan pembangunan di Kalimantan Tengah. Pajak kendaraan bermotor sangat berhubungan dengan kendaraan bermotor dan jalan raya. Berdasarkan hal tersebut, maka sangatlah wajar apabila masyarakat yang menggunakan kendaraan bermotor dibebankan secara wajib untuk membayar pajak dari segi materil oleh pemerintah daerah. Sehingga alokasi pembebanan tersebut dapat digunakan untuk pembangunan, pengembangan dan pemeliharaan jalan raya.

Atas dasar hal yang telah disampaikan di atas, maka Dinas Pendapatan Daerah harus mampu menunjukkan partisipasinya dalam proses pembangunan daerah sesuai dengan visi dan misi yang telah ditetapkan. Dalam upaya peningkatan penerimaan pajak kendaraan bermotor, sudah ada beberapa strategi 
yang dilaksanakan. Strategi kebijakan yang telah dilaksanakan Dipenda tersebut, secara umum memberikan dampak yang cukup signifikan terhadap pendapatan daerah di Kalimantan Tengah. Hal ini tercermin dari meningkatnya penerimaan dari target pendapatan jenis pajak kendaraan bermotor, yang mana pada tahun 2012 target PKB yang ditetapkan adalah Rp. 160.365.000.000,00 dan realisasi penerimaan melampai target sebesar Rp. 177.692.839.789,00. Sedangkan pada tahun 2013 target PKB adalah Rp. 182.212.460.000,00 dan realisasi penerimaan juga melampai target sebesar Rp. 210.336.015.940,00. Kemudian pada tahun 2014 target PKB adalah Rp. 232.796.200.000,00 dan realisasi penerimaan juga mampu melampai target sebesar Rp.236.116.301.705,00. Realisasi penerimaan PKB pada dasarnya selalu di atas $100 \%$ setiap tahunnya. Tetapi pada tahun 2014 PAD mengalami penurunan penerimaan dan tidak mampu melampaui target, bahkan jumlah kendaraan bermotor yang membayar pajak juga berkurang.

Berdasarkan data selama periode 2012-2014 menunjukkan bahwa tidak semua jenis kendaraan bermotor mengalami peningkatan dan dapat melampaui target yang telah ditetapkan, salah satunya seperti PKB jenis Sepeda Motor yang merupakan penyumbang penerimaan terbesar untuk pajak kendaraan bermotor. Penerimaan pajak sepeda motor setiap tahunnya terus mengalami peningkatan. Namun secara persentase kontribusi penerimaan pajak sepeda motor terhadap PAD mengalami turun naik (berfluktuasi) dan total wajib pajak sepeda motor yang membayar pajak juga mengalami penurunan, sehingga yang menjadi permasalahan disini adalah penerimaan pajak sepeda motor yang berfluktuasi karena adanya wajib pajak yang tidak membayar pajak sepeda motornya. Hal inilah yang kemudian mengakibatkan terjadinya kebocoran potensi pendapatan dari penerimaan pajak sepeda motor yang seharusnya dengan semakin bertambahnya jumlah sepeda motor setiap tahunnya, maka target akan mampu tercapai dan semakin meningkatkan juga penerimaan Pendapatan Asli Daerah di Kalimantan Tengah melalui penerimaan pajak sepeda motor.

Dengan peran yang dimiliki Dipenda sebagai lembaga penerima sekaligus lembaga pelayanan, maka keberhasilan Dipenda dalam melaksanakan upaya pencapaian target guna meningkatkan pendapatan daerah sebenarnya ditentukan oleh dua faktor utama, yaitu faktor (1) internal yang dapat dikontrol (2) eksternal yang tidak dapat di kontrol. Sebab bagi Dipenda, target penerimaan yang belum tercapai pada suatu periode belum tentu disebut gagal. Sedangkan masyarakat sebagai wajib pajak yang dilihat dari sisi kewajibannya, berhak untuk menuntut adanya peningkatan pelayanan. Sehingga tidak lagi terjadi perlawanan terhadap pajak, karena wajib pajak tidak memenuhi kewajiban membayar pajak.

Berdasarkan latar belakang di atas, maka tujuan dari penelitian ini adalah untuk (1) Menganalisis strategi pemerintah daerah dalam meningkatkan penerimaan pajak kendaraan bermotor jenis sepeda motor di Kalimantan Tengah (2) Menganalisis faktor penghambat dan pendukung yang mempengaruhi peningkatan penerimaan pajak kendaraan bermotor jenis sepeda motor di Kalimantan Tengah. 


\section{TINJAUAN PUSTAKA}

\section{Otonomi Daerah}

Menurut Undang-Undang Nomor 23 Tahun 2014 tentang Otonomi Daerah mengatakan bahwa Otonomi Daerah adalah hak, wewenang, dan kewajiban daerah otonom untuk mengatur dan mengurus sendiri Urusan Pemerintahan dan kepentingan masyarakat setempat dalam sistem Negara Kesatuan Republik Indonesia. Sedangkan menurut Waluyo: ${ }^{1}$

"Otonomi daerah diartikan sebagai hak daerah dan masyarakat untuk memperoleh keleluasaan bergerak dan kesempatan untuk menggunakan prakarsa sendiri, atas segala macam nilai dan potensi yang dikuasai untuk mengurus kepentingan publik, baik yang menyangkut pemberian pelayanan kepada masyarakat melalui pemberian fasilitas dan bimbingan terhadap masyarakat, maupun untuk meningkatkan kesejahteraan rakyat melalui pelaksanaan pembangunan."

Menurut Undang-Undang Nomor 23 Tahun 2014 tentang Otonomi Daerah, dikenal beberapa azaz penyelenggaraan pemerintahan di daerah, yaitu :

1. Azas Desentralisasi adalah penyerahan urusan pemerintahan oleh pemerintah pusat kepada daerah otonom berdasarkan asas otonomi.

2. Azas Dekonsentrasi adalah pelimpahan sebagian urusan pemerintahan yang menjadi kewenangan pemerintah pusat kepada gubernur sebagai wakil pemerintah pusat, kepada instansi vertikal di wilayah tertentu, dan/atau kepada gubernur dan bupati/walikota sebagai penanggung jawab urusan pemerintahan umum.

3. Azas Pembantuan adalah penugasan dari pemerintah pusat kepada daerah otonom untuk melaksanakan sebagian urusan pemerintahan yang menjadi kewenangan pemerintah pusat atau dari pemerintah daerah provinsi kepada daerah kabupaten/kota untuk melaksanakan sebagian urusan pemerintahan yang menjadi kewenangan daerah provinsi.

Dalam pelaksanaan otonomi daerah, menurut Sunarno keuangan daerah menjadi tolak ukur kemajuan pembangunan pembangunan yang ada di daerah. Berkaitan dengan hal tersebut, maka daerah harus diberi hak untuk mendapatkan sumber-sumber keuangan untuk membiayai segala aktivitas pembangunan di daerahnya. ${ }^{2}$ Sedangkan Koswara mengatakan bahwa keberhasilan pelaksanaan otonomi daerah tidak terlepas dan bergantung kepada sikap mental dan perilaku serta kemampuan profesional aparatur pemerintah daerah. Karena potensi yang dimiliki daerah tidak akan bisa optimal bila pemimpin daerahnya tidak memahami dan mengetahui cara memenejemen dan mengelola keuangan daerahnya. ${ }^{3}$

Berdasarkan Undang-Undang Nomor 23 Tahun 2014 Pasal 283 tentang Pemegang Kekuasaan Pengelolaan Keuangan Daerah dikatakan bahwa

\footnotetext{
${ }^{1}$ Waluyo, Manajemen Publik (Konsep, Aplikasi Dan Implementasi Dalam Pelaksanaan Otonomi Daerah), Sinar Grafika, Bandung, 2007, hlm. 141

${ }^{2}$ Sunarno, Siswanto, Hukum Pemerintahan Daerah Di Indonseia, Sinar Grafika, Jakarta, 2009, hlm. 211

${ }^{3}$ Waluyo, Manajemen Publik (Konsep, Aplikasi Dan Implementasi Dalam Pelaksanaan Otonomi Daerah), Sinar Grafika, Bandung, 2007, hlm. 147
} 
pengelolaan keuangan daerah merupakan bagian yang tidak terpisahkan dari penyelenggaraan urusan pemerintahan yang menjadi kewenangan daerah sebagai akibat dari penyerahan urusan pemerintahan. Pengelolaan keuangan daerah sebagaimana dimaksud pada ayat (1) dilakukan secara tertib, taat pada ketentuan peraturan perundang-undangan, efisien, ekonomis, efektif, transparan, dan bertanggung jawab dengan memperhatikan rasa keadilan, kepatutan, dan manfaat untuk masyarakat.

Kepala daerah adalah pemegang kekuasaan pengelolaan keuangan daerah dan mewakili pemerintah daerah dalam kepemilikan kekayaan daerah yang dipisahkan. Dalam melaksanakan kekuasaan sebagaimana dimaksud pada ayat (1) kepala daerah melimpahkan sebagian atau seluruh kekuasaannya yang berupa perencanaan, pelaksanaan, penatausahaan, pelaporan dan pertanggungjawaban, serta pengawasan keuangan daerah kepada pejabat perangkat daerah. Pelimpahan sebagian atau seluruh kekuasaan sebagaimana dimaksud pada ayat (2) didasarkan pada prinsip pemisahan kewenangan antara yang memerintahkan, menguji, dan yang menerima atau mengeluarkan uang. Sumber pendapatan daerah terdiri atas:

a. Pendapatan asli daerah meliputi (1) Pajak daerah (2) Retribusi daerah (3) Hasil pengelolaan kekayaan daerah yang dipisahkan, dan (4) Lain-lain pendapatan asli daerah yang sah.

b. Pendapatan transfer.

c. Lain-lain pendapatan daerah yang sah.

Pajak daerah dan retribusi daerah ditetapkan dengan undang-undang yang pelaksanaan di daerah diatur lebih lanjut dengan perda. Pemerintah daerah dilarang melakukan pungutan atau dengan sebutan lain di luar yang diatur dalam undang-undang. Hasil pengelolaan kekayaan daerah yang dipisahkan sebagaimana dimaksud dalam pasal 285 ayat (1) huruf a angka 3 dan lain-lain pendapatan asli daerah yang sah sebagaimana dimaksud dalam pasal 285 ayat (1) huruf a angka 4 ditetapkan dengan perda dengan berpedoman pada ketentuan peraturan perundang-undangan.

Menurut Mahmudi salah satu tujuan pelaksanaan otonomi daerah dan desentralisasi fiskal adalah untuk meningkatkan kemandirian daerah dan mengurangi ketergantungan fiskal terhadap pemerintah pusat. Peningkatan kemandirian daerah sangat erat kaitannya dengan kemampuan daerah dalam mengelola Pendapatan Asli daerah (PAD). Semakin tinggi kemampuan daerah dalam menghasilkan PAD, maka semakin besar pula diskresi daerah untuk menggunakan PAD tersebut sesuai dengan aspirasi, kebutuhan, dan prioritas pembangunan daerah. Peningkatan PAD tidak hanya menjadi perhatian pihak eksekutif, namun legislatif pun berkepentingan sebab besar kecilnya PAD akan mempengaruhi struktur gaji anggota dewan. ${ }^{4}$

\section{Konsep Strategi}

Strategi menurut Stephan Robbins ${ }^{5}$ adalah penentuan tujuan jangka panjang perusahaan dan memutuskan arah tindakan serta mendapatkan sumber-sumber

\footnotetext{
${ }^{4}$ Mahmudi, Manajemen Keuangan Daerah, Erlangga, Jakarta, 2010, hlm. 18

${ }^{5}$ Morissan, Manajemen Public Relations : Strategi Menjadi Humas Profesional, Kencana, Jakarta 2008, hlm. 152
} 
yang diperlukan untuk mencapai tujuan. Selanjutnya menurut Deitiana ${ }^{6}$ untuk dapat mencapai misi yang ditetapkan dengan efektif dan efisien maka organisasi perlu menetapkan strategi tertentu. Oleh karena itu strategi dapat diartikan sebagai (1) Rencana tindakan untuk mencapai misi (2) Memperlihatkan bagaimana misi akan dicapai (3) Setiap perusahaan mempunyai strategi bisnis (4) Area fungsional mempunyai strategi. Sedangkan pengertian strategi menurut Hamel dan Prahalad dalam Sumarsan (2013): ${ }^{7}$

"Strategi merupakan tindakan yang bersifat senantiasa meningkat/ incremental dan terus-menerus, serta dilakukan berdasarkan sudut pandang tentang apa yang diharapkan oleh para pelanggan di masa mendatang. Jadi strategi sering kali di mulai dari apa yang dapat terjadi dan bukan dimulai dari apa yang terjadi."

Strategi menurut Muljono ${ }^{8}$ adalah arah atau jalan yang ditempuh organisasi dalam rangka menjalankan misinya untuk menuju pencapaian visi. Menurut Kamus Besar Bahasa Indonesia (KBBI) dalam strategi adalah ilmu dan seni menggunakan semua sumber daya untuk melaksanakan kebijaksanaan tertentu dalam perang maupun damai. Intinya strategi adalah pilihan untuk melakukan aktivitas yang berbeda atau untuk melaksanakan aktivitas dengan cara berbeda dari pesaing.

Menurut Fred R. David ${ }^{9}$ Strategi intensifikasi, dalam implementasinya memerlukan usaha-usaha intensif untuk meningkatkan posisi persaingan perusahaan produk-produk yang sudah ada. Yang termasuk dalam kategori strategi ini antara lain:

a. Strategi Penetrasi Pasar (Market Peneration Strategy), adalah berusaha untuk meningkatkan market share suatu produk atau jasa melalui usaha pemasaran yang lebih besar. Strategi ini dapat diimplementasikan baik secara sendiri-sendiri atau bersama dengan strategi lain untuk dapat menambah jumlah tenaga penjual, biaya iklan, items untuk promosi penjualan dan usahausaha promosi lainnya. Jadi tujuan strategi ini adalah untuk meningkatkan pangsa pasar dengan usaha pemasaran yang maksimal.

b. Strategi Pengembangan Pasar (Market Development Strategy), strategi ini bertujuan untuk memperkenalkan produk-produk atau jasa yang ada sekarang ke daerah-daerah yang secara geografis merupakan daerah baru. Dalam perspektif global, pengembangan pasar berskala internasional sudah banyak dilakukan oleh perusahaan-perusahaan. Namun industri tertentu akan menghadapi kesulitan dalam bersaing pasar local. Jadi tujuan strategi ini adalah untuk memperbesar pangsa pasar.

${ }^{6}$ Deitiana, Manajemen Operasional Strategi Dan Analisa (Services Dan Manufaktur), Mitra Wacana Media, Jakarta, 2011, hlm. 18

7 Sumarsan, Tax Review Dan Strategi Perencanaan Pajak. Edisi 2, PT. Indeks, Jakarta, 2013, hlm. 112,113

${ }^{8}$ Muljono, Buku Pintar Strategi Bisnis Koperasi Simpan Pinjam, Andi, Yogyakarta, 2012, hlm. 15

9 Nteseo, Agustiany, "Tipologi Strategi: Strategi Utama Yang Merupakan Jabaran Dari Strategi Generik", diakses dari http://www.Agustianya.blogspot.com/2012/04/artikel-tugasmanajemen-strategi.html?m=1, pada tanggal 06 Februari 2015 pukul 15.47 
c. Strategi Pengembangan Produk (Product Development Strategy), adalah strategi yang bertujuan agar perusahaan dapat meningkatkan penjualan dengan cara meningkatkan atau memodifikasi produk-produk atau jasa yang ada sekarang. Strategi ini biasanya memerlukan penelitian yang luas dan tajam serta membutuhkan biaya yang cukup besar. Jadi, tujuan strategi ini adalah untuk memperbaiki dan mengembangkan produk yang sudah ada.

Menurut Sujarto ${ }^{10}$ penentuan pilihan strategis dilaksanakan dengan suatu rangkaian kegiatan berproses yang disebut sebagai Proses Pilihan Strategis. Proses ini pada dasarnya dilandasi oleh tiga produk utama yaitu adanya masukan (input) yang kemudian dianalisis untuk memperoleh keluaran (output) yang berupa (disain produk strategis) yang akan menjadi landasan tindakan penyelesaian masalah. Hasil dari disain produk strategis ini akan dievaluasi untuk dikembangkan di dalam usaha pengambilan keputusan lanjut. Sedangkan menurut Muljono $^{11}$ proses manajemen strategi secara umum terdiri atas 5 tahap, yaitu (1) Menetapkan Arah Dan Misi Organisasi (2) Memahami Lingkungan Internal Dan Eksternal (3) Memformulasi Strategi (4) Mengimplementasikan Strategi (50 Mengevaluasi Dan Mengawasi Strategi.

Formulasi strategi melibatkan penetapan serangkaian tindakan yang tepat guna untuk mencapai tujuan perusahaan. Formulasi strategi ini meliputi pengembangan misi bisnis, analisis SWOT: mengidentifikasi peluang dan ancaman eksternal serta mengukur dan menetapkan kelemahan dan kekuatan dan menetapkan tujuan jangka panjang. SWOT merupakan singkatan dari strength (kekuatan), weakness (kelemahan), opportunity (peluang) dan threats (ancaman). Pendekatan ini mencoba menyeimbangkan kekuatan dan kelemahan internal organisasi dengan peluang dan ancaman lingkungan eksternal organisasi.

a. Kekuatan (strength) adalah suatu kondisi di mana perusahaan mampu melakukan semua tugasnya secara sangat baik (di atas rata-rata industri).

b. Kelemahan (weakness) adalah kondisi di mana perusahan kurang mampu melaksanakan tugasnya dengan baik dikarenakan sarana dan prasarananya kurang mencukupi.

c. Peluang (opportunity) adalah suatu potensi bisnis menguntungkan yang dapat diraih oleh perusahaan yang masih belum dikuasai pesaing dan masih belum tersentuh oleh pihak manapun.

d. Ancaman (threats) adalah suatu keadaan dimana perusahaan mengalami kesulitan yang disebabkan oleh kinerja pesaing, yang jika dibiarkan maka perusahaan akan mengalami kesulitan di kemudian hari.

\section{Pajak Kendaraan Bermotor}

Pengertian pajak daerah menurut Siahaan" ${ }^{12}$ merupakan "Pajak yang ditetapkan oleh pemerintah daerah dengan peraturan daerah (Perda), yang wewenang pemungutannya dilaksanakan oleh pemerintah daerah dan hasilnya digunakan untuk membiayai pengeluaran pemerintah daerah dalam melaksanakan penyelenggaraan pemerintahan dan pembangunan daerah". Pajak daerah di

10 Sujarto, Pilihan Strategis : Suatu Teknik Pengambilan Keputusan Dalam Perencanaan Wilayah Dan Kota, ITB, Bandung, 2001, hlm. 11

11 Muljono, Buku Pintar Strategi Bisnis Koperasi Simpan Pinjam, Andi, Yogyakarta, 2012, hlm. 19

${ }^{12}$ Siahaan, Pajak Daerah \& Retribusi Daerah. Edisi Revisi, Rajawali Pers, Jakarta, 2013, hlm. 9 
Indonesia terbagi menjadi dua, yaitu pajak provinsi dan pajak kabupaten/kota. Berdasarkan Undang-Undang Nomor 28 Tahun 2009 yang ditetapkan, jenis pajak daerah yaitu sebagai berikut:

Tabel 1

Jenis Pajak Daerah

\begin{tabular}{|c|l|l|}
\hline $\begin{array}{c}\text { N } \\
\text { o. }\end{array}$ & \multicolumn{1}{|c|}{$\begin{array}{c}\text { Pajak } \\
\text { Daerah }\end{array}$} & \multicolumn{1}{|c|}{ Jenis Pajak Daerah } \\
\hline 1 & $\begin{array}{l}\text { Pajak } \\
\text { Provinsi }\end{array}$ & $\begin{array}{l}\text { Pajak Kendaraan Bermotor, Bea Balik Nama Kendaraan } \\
\text { Bermotor, Pajak Bahan Bakar Kendaraan Bermotor, Pajak } \\
\text { Air Permukaan, dan Pajak Rokok. }\end{array}$ \\
\hline 2 & $\begin{array}{l}\text { Pajak } \\
\text { Kabupaten }\end{array}$ & $\begin{array}{l}\text { Pajak Hotel, Pajak Restoran, Pajak Hiburan, Pajak Reklame, } \\
\text { Pajak Penerangan Jalan, Pajak Mineral Bukan Logam Dan } \\
\text { Batuan, Pajak Parkir, Pajak Air Tanah, Pajak Sarang Burung } \\
\text { Kalet, Pajak Bumi Dan Bangunan Perdesaan Dan }\end{array}$ \\
& Kota & $\begin{array}{l}\text { Perkotaan, dan Pajak Perolehan Hak Atas Tanah Dan } \\
\text { Bangunan. }\end{array}$ \\
\end{tabular}

Sumber : Siahaan (2013: 64-65), data diolah peneliti

Menurut Peraturan Daerah Provinsi Kalimantan Tengah Nomor 7 Tahun 2010 tentang Pajak Daerah mengatakan bahwa Pajak Kendaraan Bermotor (PKB) adalah pajak atas kepemilikan dan/atau penguasaan Kendaraan Bermotor. Sedangkan menurut Mahmudi ${ }^{13}$ Pajak Kendaraan Bermotor (PKB) pada umumnya merupakan penyumbang PAD terbesar bagi pemerintah provinsi. Adapun jenis pajak kendaraan bermotor adalah sebagai berikut:

Tabel 2

Jenis Pajak Kendaraan Bermotor

\begin{tabular}{|c|l|}
\hline No. & \multicolumn{1}{|c|}{$\begin{array}{c}\text { Jenis Penerimaan } \\
\text { Pajak Kendaraan Bermotor }\end{array}$} \\
\hline 1 & Sedan, Jeep, Minibus (Pribadi) \\
\hline 2 & Sedan, Jeep, Minibus (Umum) \\
\hline 3 & Bus, Micro Bus (Pribadi) \\
\hline 4 & Bus, Micro Bus (Umum) \\
\hline 5 & Truck, Light Truck, Pic Up (Pribadi) \\
\hline 6 & Truck, Light Truck, Pic Up (Umum) \\
\hline 7 & Kendaraan Khusus (Pribadi) \\
\hline 8 & Kendaraan Khusus (Umum) \\
\hline 9 & Sepeda Motor \\
\hline 10 & Kendaraan Bermotor Yang Dioperasikan Di Atas Air \\
\hline
\end{tabular}

Sumber : Dipenda Provinsi Kalimantan Tengah, data diolah peneliti

Dalam upaya melakukan intensifikasi PKB, menurut Mahmudi ${ }^{14}$ pemerintah daerah terkadang menghadapi kesulitan. Kesulitan tersebut terkait dengan berfluktuasinya transaksi kendaraan bermotor di daerah. Meskipun PKB sangat

${ }^{13}$ Mahmudi, Manajemen Keuangan Daerah, Erlangga, Jakarta, 2010, hlm. 22

${ }^{14}$ Mahmudi, Manajemen Keuangan Daerah, Erlangga, Jakarta, 2010, hlm. 23 
potensial bagi daerah, tetapi pemerintah daerah harus juga melakukan upaya pengendalian yang memadai. Sebab tinggi rendahnya pertumbuhan populasi kendaraan bermotor di suatu daerah dapat menimbulkan masalah kemacetan, polusi, dan meningkatkan angka kecelakaan. Kerjasama pemerintah daerah dengan pihak kepolisian juga perlu dioptimalkan misalnya melalui operasi lalu lintas untuk meminimalisir jumlah tunggakan pajak.

\section{METODE PENELITIAN}

Menurut Tajoer Ridjal dalam Burhan Bungin (2001: 124) penelitian yang menggunakan pendekatan kualitatif bertujuan menggali atau membangun suatu proposisi atau menjelaskan makna di balik realita. Dalam penelitian ini yang digunakan adalah pendekatan penelitian deskriptif kualitatif. Dipilihnya jenis penelitian ini dengan mempertimbangkan bahwa peneliti akan dapat menggali informasi secara lebih dalam tentang kebijakan pemerintah daerah dalam meningkatkan sumber penerimaan daerah, yang membedakan dengan penelitianpenelitian terdahulu. Lokasi penelitian ini dilakukan di Dinas Pendapatan Daerah (DIPENDA) Provinsi Kalimantan Tengah. Lokasi ini dipilih karena DIPENDA merupakan bagian dari perangkat daerah yang menangani tentang Pendapatan Asli Daerah (PAD) di tingkat provinsi pada sektor pajak, terutama mengenai jenis pajak kendaraan bermotor jenis sepeda motor. Fokus penelitian ini mengenai:

1. Strategi yang dilakukan Pemerintah Daerah dalam meningkat penerimaan pajak kendaraan bermotor jenis sepeda motor di Kalimantan Tengah. Indikator Strategi Intensifikasi, yaitu terdiri dari (a) Strategi penetrasi pasar (b) Strategi pengembangan pasar, dan (c) Strategi pengembangan produk.

2. Faktor penghambat dan pendukung yang mempengaruhi peningkatan penerimaan pajak kendaraan bermotor jenis sepeda motor di Kalimantan Tengah. Indikator faktor penghambat dan pendukung, terdiri dari (a) Internal, dan (b) Eksternal.

Teknik pengumpulan data yang digunakan dalam penelitian ini dilakukan melalui (1) Observasi (2) Wawancara, yang diperoleh dari Kepala Dinas Pendapatan Daerah Provinsi Kalimantan Tengah, Kepala Bidang Pajak Daerah, Kepala Seksi PKB dan BBNKB, Pelaksana Seksi Penetapan Dan Penerimaan di UPTPPD Palangka Raya dan Wajib Pajak Kendaraan Bermotor (3) Dokumentasi. Sedangkan untuk analisis data dalam penelitian berlangsung bersamaan dengan proses pengumpulan data melalui tiga tahap model air, yaitu reduksi data, penyajian data, dan verifikasi.

\section{HASIL PENELITIAN}

\section{Keadaan Wilayah}

Dinas Pendapatan Daerah adalah salah satu instansi pemerintah yang bertugas membantu Gubernur dalam melaksanakan kewenangan desentralisasi dan dekonsentrasi di Bidang Pendapatan Daerah sesuai dengan kebijaksanaan yang ditetapkan berdasarkan peraturan perundang-undangan yang berlaku. Dalam penelitian ini peneliti berfokus pada Bidang Pajak Daerah terutama pada seksi Pajak Kendaraan Bermotor (PKB) dan Bea Balik Nama Kendaraan Bermotor (BBNKB). Dimana penangan pajak kendaraan bermotor jenis sepeda motor saat ini, menjadi permasalahan serius seiring dengan meningkatnya pertumbuhan 
penduduk akibat arus urbanisasi, migrasi dan aktivitas ekonomi. Adapun realisasi penerimaan dari Pajak Sepeda Motor di Kalimantan Tengah selama tiga tahun terakhir dari tahun 2012-2014, dapat di lihat pada tabel berikut ini :

Tabel 3

Realisasi Penerimaan Pajak Sepeda Motor Tahun 2012-2014

\begin{tabular}{|c|c|c|c|}
\hline \multirow{2}{*}{ Tahun } & \multicolumn{2}{|c|}{ Pajak Sepeda Motor } & \multirow{2}{*}{$\%$} \\
\cline { 2 - 3 } & $\begin{array}{c}\text { Target Perubahan } \\
(\mathbf{R p})\end{array}$ & $\begin{array}{c}\text { Penerimaan } \\
(\mathbf{R p})\end{array}$ & \\
\hline 2012 & $70.000 .000 .000,00$ & $68.610 .225 .334,00$ & 98,01 \\
\hline 2013 & $69.000 .000 .000,00$ & $77.373 .327 .150,00$ & 112,14 \\
\hline 2014 & $93.504 .000 .000,00$ & $82.207 .637 .950,00$ & 87,92 \\
\hline
\end{tabular}

Sumber : Dipenda Provinsi Kalimantan Tengah, data diolah peneliti

Data di atas menunjukkan adanya peningkatan penerimaan pajak sepeda motor setiap tahunnya. Namun secara persentase, kontribusi pajak sepeda motor terhadap PKB mengalami turun naik penerimaan (berfluktuasi) dan realisasinya penerimaan masih mengalami turun naik pencapaian target. Adapun Total Sepeda Motor di Kalimantan Tengah dari tahun 2013-2014 yang diperoleh dari total wajib pajak yang membayar pajak, dapat di lihat pada tabel berikut ini :

Tabel 4

Total Sepeda Motor Di Kalimantan Tengah Tahun 2013-2014

\begin{tabular}{|c|c|c|c|c|}
\hline \multirow{2}{*}{ Tahun } & \multicolumn{3}{|c|}{ Jenis Sepeda Motor } & \multirow{2}{*}{ Total (Unit) } \\
\cline { 2 - 4 } & Baru (Unit) & Ulang (Unit) & Mutasi (Unit) & \\
\hline 2013 & 81.385 & 318.866 & 1.313 & 401.564 \\
\hline 2014 & 80.462 & 312.554 & 1.005 & 394.023 \\
\hline
\end{tabular}

Sumber : Dipenda Provinsi Kalimantan Tengah, data diolah peneliti

Data di atas menunjukkan bahwa dari 401.564 unit terdapat 89.010 unit sepeda motor yang belum melakukan registrasi tahunan pada tahun 2014 dan hanya 312.554 unit sepeda motor yang melakukan pendaftaran ulang. Yang artinya Kalimantan Tengah mengalami banyak kebocoran potensi pendapatan yang diperoleh dari pajak sepeda motor. Kebocoran potensi penerimaan sepeda motor tersebut misalnya di hitung seperti ini, seandainya saja dari seluruh unit sepeda motor yang belum melakukan registrasi tahunan dalam 1 unit sepeda motor tesebut dikenakan PKB paling kecil sebesar Rp 150.000,00 maka seandainya 89.010 unit tersebut dikali Rp 150.000,00 ini berarti total kebocoran potensi pendapatan dari pajak sepeda motor sebesar Rp 13.351.500.000,00 (Tiga belas miliar tiga ratus lima puluh satu juta lima ratus ribu rupiah). Total kebocoran potensi pendapatan ini hanya dilihat dari satu cc sepeda motor dan belum dilihat dari cc sepeda motor lainnya yang nominal pajak yang lebih besar dari contoh yang telah disampaikan di atas. Karena beradasarkan Perda Nomor 7 Tahun 2010 pasal 6 ayat (1) PKB di hitung dari nilai jual kendaraan bermotor dikali bobot (kerusakan jalan dan lingkungan) dan bobot di Kalimantan Tengah dikenakan sebasar Rp. 35.000,00 untuk setiap sepeda motor. Karena seandainya saja dari Rp 13.351.500.000,00 kebocoran potensi tersebut dijumlahkan dengan total 
penerimaan pada tahun 2014 yang sebesar Rp 82.207.637.950,00 maka seharusnya total penerimaannya adalah sebesar Rp 95.559.137.950 yang artinya target yang ditetapkan sebesar $\mathrm{Rp} 93.504 .000 .000,00$ pada tahun 2014 dapat tercapai dan persentase penerimaan mengalami peningkatan di atas $100 \%$.

\section{Strategi Intensifikasi Dipenda Dalam Meningkatkan Penerimaan PKB Jenis Sepeda Motor Di Kalimantan Tengah}

Strategi intensifikasi merupakan strategi-strategi yang dalam implementasinya memerlukan usaha-usaha intensif untuk meningkatkan posisi persaingan perusahan produk-produk yang ada. Yang secara umum dilaksanakan melalui strategi penetrasi pasar, pengembangan pasar dan pengembangan produk.

a. Strategi Penetrasi Pasar

Strategi penetrasi pasar melalui koordinasi dan kerjasama ini menggambarkan bahwa Bidang Pajak Daerah Provinsi Kalimantan Tengah sudah berusaha meningkatkan penerimaan pajak kendaraan berdasarkan kebutuhan masyarakat meskipun masih belum maksimal dalam pelaksanaannya, sehingga kedepannya koordinasi dengan tingkat kabupaten/kota menjadi lebih baik dan meningkatkan kualitas kegiatan rajia tersebut serta diharapkan program tersebut dapat berjalan terus dan semakin baik lagi kedepannya. Supaya UU Nomor 32 Tahun 2015 dalam hal pengelolaan keuangan melalui transparansi dan tanggung jawab dalam memberikan manfaat bagi masyarakat dapat terlaksana.

b. Strategi Pengembangan Pasar

Strategi pengembangan pasar melalui sosialisasi dinilai masih belum optimal dalam pelaksanannya karena tidak ada sosialisasi guna meningkatkan pangsa pasar dengan cara memperkenalkan produk ke daerah baru, seperti lingkungan pendidikan dan instansi pemerintah. Pengembangan pasar melalui mobil SAMSAT keliling dan sosialisasi hendaknya lebih ditingkatkan lagi kedepannya, supaya dapat meningkatkan pangsa pasar dan terlaksananya UU Nomor 23 Tahun 2014 tentang pengelolaan keuangan yang dilakukan secara efisien dengan memberikan manfaat bagi masyarakat.

c. Strategi Pengembangan Produk

Strategi pengembangan produk yang dijalankan oleh Dipenda di nilai masih belum maksimal dalam penerapan pergub tersebut karena masih ada wajib pajak yang belum membayar pajak, sehingga data wajib pajak pajak belum akurat. Strategi pengembangan produk dalam meningkatkan pelayanan melalui sistem online diharapkan dapat ditingkatkan lagi agar memacu partisipasi wajib pajak. Karena mekanisme yang praktis dan mudah, sehingga model layanan online lainnya dapat terealisasi dan terlaksananya UU Nomor 23 tahun 2014 yang dilakukan secara efisien, ekonomis dan efektif yang bermanfaat untuk masyarakat.

\section{PEMBAHASAN}

\section{Strategi Intensifikasi Berdasarkan Hasil Penelitian}

Menurut Fred R. David Strategi intensifikasi merupakan strategi-strategi yang dalam implementasinya memerlukan usaha-usaha intensif untuk meningkatkan posisi persaingan perusahan produk-produk yang ada. Ini berarti bahwa strategi intensif mengandung makna akan sebuah keinginan dan upaya seorang individu maupun organisasi untuk selalu meningkatkan kualitas 
pelayanan melalui produk-produk yang ada. Dalam pembahasan ini penulis akan membahas ketiga kelompok strategi intensif yang terdiri dari (a) Strategi Penetrasi Pasar, (b) Strategi Pengembangan Pasar dan (c) Strategi Pengembangan Produk yang akan di nilai dari hasil penelitian mengenai strategi pemerintah daerah dalam meningkatkan penerimaan PKB jenis sepeda motor di Kalimantan Tengah.

\section{Strategi Penetrasi Pasar Berdasarkan Hasil Penelitian}

Selama ini Dipenda menjalankan strategi penetrasi pasar dengan cara meningkatkan sinergitas koordinasi dan kerjasama dengan instansi terkait untuk mendorong peningkatan penerimaan pajak daerah yang salah satunya terdiri atas pajak sepeda motor. Selama ini koordinasi dan kerjasama yang baik dengan pihak kepolisian dan Jasa Raharja. Dipenda juga sudah berusaha melakukan koordinasi dan kerjasama yang baik dengan instansi terkait yang ada di kabupaten/kota. Namun dalam pelaksanaannya masih ada sebagian instansi yang masih belum mau bekerjasama dalam operasional pemungutan pajak daerah guna meningkatkan penerimaan pajak kendaraan bermotor. Kurangnya koordinasi dengan instansi di tingkat kabupaten/kota yang belum mantap inilah yang mengakibatkan strategi penetrasi pasar ini masih belum maksimal dalam pelaksanaannya. Berdasarkan hal di atas Dipenda Provinsi Kalimantan Tengah di nilai masih belum maksimal kualitas pelayanannya, karena masih kurangnya kerjasama dari sebagian instansi di kabupateng/kota dalam meningkatkan kesadaran wajib pajak kendaraan bermotor. Hal ini sesuai dengan strategi penetrasi pasar (market peneration strategy), adalah berusaha untuk meningkatkan market share suatu produk atau jasa melalui usaha pemasaran yang lebih besar. Strategi ini dapat diimplementasikan baik secara sendiri-sendiri atau bersama, yang tujuannya untuk meningkatkan kesadaran para wajib pajak untuk membayar pajak kendaraannya. Meskipun pihak kepolisian dan Jasa Raharja sudah memberikan dukungan kepada Dipenda Provinsi Kalimantan Tengah, namun masih ada instansi terkait lainnya yang belum mau bekerjasama untuk meningkatkan kesadaran wajib pajak supaya mau membayar pajak. Sehingga peneliti menyimpulkan strategi penetrasi pasar yang dilakukan oleh Dipenda masih belum maksimal.

\section{Strategi Pengembangan Pasar Berdasarkan Hasil Penelitian}

Strategi penetrasi pasar melalui mobil SAMSAT keliling ini dilakukan untuk dapat lebih mendekatkan pelayanan kepada masyarakat yang ada di daerah terpencil. Layanan mobil SAMSAT keliling ini bisa digunakan untuk membayar pajak di seluruh daerah. Namun strategi pengembangan pasar ini masih belum maksimal, sebab selama ini sosialisasi masih belum pernah dirasakan oleh masyarakat dan masih banyak masyarakat yang belum mengetahui keberadaan dari mobil SAMSAT keliling yang sudah disediakan tersebut. Berdasarkan hal tersebut disimpulkan bahwa dalam strategi pengembangan pasar Dipenda masih kurang maksimal, karena Dipenda belum mampu secara maksimal dalam memperkenalkan salah satu jasa layanan pembayaran pajak yang sudah disediakan kepada wajib pajak kendaraan bermotor seperti mobil SAMSAT keliling kepada masyarakat. Sehingga mengakibatkan masyarakat melalaikan kewajibannya dalam membayar pajak kendaraannya dan pengembangan pasar ini perlu untuk 
ditingkatkan dengan cara memperkenalkan produk masyarakat dengan mempromosikan jasa layanan ke daerah baru.

\section{Strategi Pengembangan Produk Berdasarkan Hasil Penelitian}

Strategi pengembangan produk yang dilakukan Dipenda adalah yang pertama melalui sistem online pengelolaan administrasi guna meningkatkan kualitas pelayanan kepada masyarakat, meskipun dalam model layanannya hanya masih di dalam kantor layanan yang digunakan oleh pegawai saja. Dalam hal ini sistem online ini di nilai masih belum maksimal karena upaya Dipenda meningkatkan penjualan dengan memperbaiki atau memodifikasi produk atau jasa yang ataupun mengembangkan yang baru dalam pelaksanaannya masih belum optimal, karena Dipenda model layanan seperti E-SAMSAT masih belum tersedia. Namun Dipenda tetap berupaya meningkatkan penerimaan salah satunya dengan menjalankan Pergub 36 Tahun 2013, yaitu kebijakan pembebasan/sanksi administrasi pemungutan pajak atau denda bunga terhadap keterlambatan pembayaran pajak, namun masih ada wajib pajak sepeda motor tetap melanggar kewajibannya. Sehingga disimpulkan bahwa strategi pengembangan produk yang dilakukan melalui sistem online dan Pergub 36 Tahun 2013 untuk meningkatkan penjualan dengan memperbaiki atau memodifikasi produk atau jasa yang ataupun mengembangkan yang baru masih belum optimal dalam penerapannya.

\section{Faktor-Faktor Yang Mempengaruhi Peningkatan Penerimaan PKB Jenis Sepeda Motor Di Kalimantan Tengah}

\section{Faktor Pendukung}

Selama ini faktor pendukung dalam meningkatkan penerimaan pajak kendaraan bermotor jenis sepeda motor, salah satunya adalah karena tersedia 14 mobil SAMSAT keliling yang ada di seluruh kabupaten/kota. Faktor pendukung lainnya adalah karena kegiatan razia dan sosialisasi yang dilaksanakan 4 kali dalam 1 tahun pada setiap UPTPPD di Kalimantan Tengah. Razia yang dilaksanakan ini dapat terlaksana karena adanya koordinasi yang baik dengan pihak kepolisian. Yang mana dalam pelaksanaan kegiatan razia tersebut, bagi pemilik kendaraan yang belum melakukan registrasi harus membuat surat pernyataan untuk segera membayar pajak di kantor SAMSAT terdekat dalam tempo paling lambat 1 minggu setelah terjaring razia. Sedangkan untuk sosialisasi dilakukan kepada masyarakat dan UPTPPD untuk meningkatkan kualitas pelayan pegawai yang memberi layanan.

\section{Faktor Penghambat}

Faktor penghambat yang mempengaruhi dalam peningkatan penerimaan pajak kendaraan bermotor jenis sepeda motor yang mengalami turun naik pencapaian target adalah karena wilayah Kalimantan Tengah yang luas dan kurangnya kesadaran masyarakat dalam menginformasikan hak kepemilikan atas kendaraan yang telah di jual dan yang sudah tidak digunakan lagi untuk melakukan aktivitas. Terhambatnya strategi intensifikasi ini juga terjadi karena kurangnya dukungan dari sebagian instansi terkait, yaitu pada tingkat kabupaten/kota yang tidak mau bekerjasama dengan provinsi dalam meningkatkan penerimaan yang menjadi pungutan provinsi guna menguatkan dan 
mengembangkan strategi yang dimiliki oleh Dipenda, sebab mereka menganggap tidak ada bagi hasil dari penerimaan yang menjadi pungutan provinsi. Kurangnya dukungan tersebut juga terjadi karena legislatif sebagai penetap kebijakan dalam hal penyediaan anggaran yang kurang mendukung kebijakan eksekutif dalam menjalankan program kerja yang telah ditetapkan. Sebab tanpa adanya anggaran maka sebagus apapun program kerja eksekutif dalam meningkatkan model layanan unggulan seperti E-SAMSAT tidak akan dapat dijalankan dan diimplementasi. Kurangnya dukungan ini terjadi karena legislatif masih belum menganggap penting program kerja yang ditetapkan oleh Dipenda.

Faktor lainnya yang menghambat penerimaan pajak sepeda motor adalah karena masih kurangnya kualitas kinerja pegawai yang berhadapan langsung dengan pembayar pajak dalam proses pelayanan yang diberikan kepada masyarakat yang sadar akan tanggung jawabnnya dalam membayar pajak, sehingga sebagian kecil dari masyarakat yang memiliki kesibukan merasa tidak mempunyai cukup banyak waktu untuk melakukan registrasi kendaraannya dan harus melewati berbagai prosedur yang panjang, sehingga kualitas pelayanan yang diberikan oleh pegawai SAMSAT juga harus lebih ditingkatkan lagi. Terhambatnya penerimaan juga terjadi karena kurang memperkenalkan mobil SAMSAT dan kurangnya sosialisasi yang diberikan kepada masyarakat, terutama di lingkungan pendidikan dan instansi pemerintah.

Faktor-faktor penyebab terhambatnya strategi pemerintah daerah, pada akhirnya akan mempengaruhi dalam meningkatkan penerimaan pajak kendaraan bermotor di Kalimantan Tengah. Namun secara garis besar, faktor yang menjadi sangat dominan mempengaruhi strategi pemerintah daerah adalah faktor internal (faktor yang datang dari dalam organisasi) dan faktor eksternal (faktor yang datang dari luar organisasi). Oleh sebab itu dari adanya faktor pendukung dan faktor penghambat Bidang Pajak Daerah ini dapat dijadikan sebagai motivasi dalam membentuk strategi peningkatan penerimaan pajak sepeda motor. Dimana Dipenda Provinsi Kalimantan Tengah telah berusaha meningkatkan kualitas pelayanan dengan menerapkan berbagai strategi agar tetap bisa menjalankan tugasnya sebaik mungkin dalam bidang pendapatan daerah, meskipun terdapat banyak faktor penghambat dalam pelaksanaan strategi guna mencapai target dan meningkatkan penerimaan PKB jenis sepeda motor di Kalimantan Tengah.

\section{KESIMPULAN}

Berdasarkan hasil penelitian dan pembahasan yang diperoleh, dapat diambil suatu kesimpulan dari strategi pemerintah daerah serta faktor pendukung dan penghambat yang mempengaruhi peningkatan penerimaan PKB jenis sepeda motor di Kalimantan Tengah.

1. Strategi pemerintah daerah adalah dengan melakukan koordinasi dan kerjasama melalui rajia, menyediakan mobil SAMSAT keliling dan sosialisasi, menggunakan sistem online dan kebijakan pembebasan/sanksi administrasi pemungutan pajak/denda dan bunga.

2. Faktor pendukung peningkataan penerimaan, yaitu karena adanya kerjasama yang baik antara Dipenda dengan pihak kepolisian dan Jasa Raharja berupa rajia dan sosialisasi dilakukan 4 kali dalam 1 tahun yang dilakukan pada masyarakat dan UPTPPD serta adanya 14 mobil SAMSAT Keliling di 
seluruh kabupaten/kota di Kalimantan Tengah yang bisa dilakukan pembaran dengan daerah tempat pembelian kendaraan.

3. Faktor penghambat yang mempengaruhi peningkatan adalah karena luas wilayah, kurangnya koordinasi Dipenda dengan intansi tingkat kabupaten/kota, kurangnya kesadaran masyarakat untuk membayar pajak dan melaporkan kepemilikan dan kondisi kendaraan yang dimilikinya agar tidak terjadinya kesalahan dalam penetapan target pada tahun berikutnya, kurang memperkenalkan mobil SAMSAT dan kurangnya sosialisasi, dan legislatif masih belum menganggap penting model pelayanan unggulan seperti ESAMSAT yang disediakan oleh Dipenda kepada wajib pajak

\section{SARAN}

Berdasarkan kesimpulan penelitian, dapat disarankan beberapa hal sebagai berikut:

1. Dipenda Provinsi Kalimantan Tengah hendaknya lebih meningkatkan koordinasi dengan pihak terkait untuk dapat lebih meningkatkan kualitas pelayanan, seperti menyediakan layanan (1) Rekening Resmi untuk menerima transfer pembayaran pajak (2) mempromosikan mobil SAMSAT melalui pameran dan sosialisasi ke lingkungan pendidikan dan instansi pemerintah serta pemberi pelayanan yang berhadapan langsung dengan pembayar pajak guna meningkatkan disiplin (3) mendorong legislatif untuk mendukung peningkatan kualitas pelayanan E-SAMSAT dan menyediakan PNSSAMSAT untuk mempermudah mekanisme pembayaran.

2. Masyarakat hendaknya lebih menumbuhkan kesadaran dan kepedulian wajib pajak terhadap manfaat membayar pajak kendaraan bermotor bagi peningkatan Pendapatan Asli Daerah (PAD) terutama dalam hal membayar pajak dan menginformasikan hak kepemilikan atas kendaraan yang telah dijual serta melaporkan kondisi kendaraan kepada pihak UPTPPD guna mencegah kesalahan dalam penetapan target pada tahun berikutnya, sehingga dapat meningkatkan penerimaan dan pembangunan di Kalimantan Tengah.

\section{DAFTAR PUSTAKA}

Bungin, Burhan (Ed.). (2001). Metodologi Penelitian Kualitatif. Jakarta: Rajawali Pers.

Deitiana, Tita. 2011. Manajemen Operasional Strategi Dan Analisa (Services Dan Manufaktur). Jakarta: Mitra Wacana Media.

Fakultas Ilmu Sosial Dan Ilmu Politik Universitas Palangka Raya. 2013. Buku Pedoman Penulisan Skripsi Jurusan Ilmu Pemerintahan. Palangka Raya: Fakultas Ilmu Sosial Dan Ilmu Politik Universitas Palangka Raya.

Mahmudi. 2010. Manajemen Keuangan Daerah. Jakarta: Erlangga.

Morissan. 2008. Manajemen Public Relations : Strategi Menjadi Humas Profesional. Jakarta: Kencana.

Muljono, Djoko. 2012. Buku Pintar Strategi Bisnis Koperasi Simpan Pinjam. Yogyakarta: Andi.

Nteseo, Agustiany. 2012. Tipologi Strategi: Strategi Utama Yang Merupakan Jabaran Dari Strategi Generik. Diakses dari http://www. 
Agustianya.blogspot.com/2012/04/artikel-tugas-manajemenstrategi.html?m=1 pada tanggal 06 Februari 2015 pukul 15.47

Peraturan Daerah Provinsi Kalimantan Tengah Nomor 7 Tahun 2010 Tentang Pajak Daerah

Rahmayanti. 2013. Skripsi Strategi Peningkatan Retribusi (Jasa) Pasar Niaga Daya Di Kota Makassar. Universitas Hasanuddin. Fakultas Ilmu Sosial Dan Ilmu Politik.

Setyaningsih, Tri. 2009. Skripsi Strategi Peningkatan Pendapatan Asli Daerah Dalam Rangka Pelaksanaan Otonomi Daerah (Studi Tentang Strategi Penerimaan Sektor Pajak Di Kabupaten Sleman). Universitas Muhammadiyah Yogyakarta. Fakultas Hukum.

Siahaan, Marihot P. 2013. Pajak Daerah \& Retribusi Daerah. Edisi Revisi. Jakarta: Rajawali Pers.

Solihin, Ismail. 2012. Manajemen Strategik. Jakarta: Erlangga

Sujarto, Djoko. 2001. Pilihan Strategis : Suatu Teknik Pengambilan Keputusan Dalam Perencanaan Wilayah Dan Kota. Bandung: ITB.

Sumarsan, Thomas. 2013.Tax Review Dan Strategi Perencanaan Pajak. Edisi 2. Jakarta: PT. Indeks.

Sunarno, Siswanto.2009. Hukum Pemerintahan Daerah Di Indonseia. Jakarta: Sinar Grafika.

Undang-Undang Nomor 28 Tahun 2009 tentang Pajak Daerah

Undang-Undang Republik Indonesia Nomor 23 Tahun 2014 Tentang Otonomi Daerah

Waluyo. 2007. Manajemen Publik (Konsep, Aplikasi Dan Implementasi Dalam Pelaksanaan Otonomi Daerah). Bandung: Sinar Grafika.

Waluyo. 2010. Perpajakan Indonesia Buku 1. Edisi 9. Jakarta: Salemba Empat.

Wulandari, Ika. 2012. Skripsi Analisis Implementasi Samsat On-Line Tiga Provinsi Pada Samsat Jakarta Selatan. Universitas Indonesia. Fakultas Ilmu Sosial Dan Ilmu Politik. 